\title{
Policy Mediated through Subject Matter Contexts: Antecedents of Subject-Bound Differences in Teachers' Perceptions of Collaboration across Subjects
}

\author{
Eyvind Elstad and Eli Lejonberg \\ Department of Teacher Education and School Research, \\ University of Oslo, Norway \\ Knut-Andreas Christophersen \\ Department of Political Science, \\ University of Oslo, Norway
}

\begin{abstract}
The main purpose of a current Norwegian educational policy is to stimulate secondary learners' basic skills. This study focuses on writing skills in schools' content areas. Teachers' collaborative activities across school subjects are central components of this endeavour: teachers will discuss with colleagues how they can better provide feedback on the students' written assignments. Providing feedback on students writing has traditionally been stressed more in some school subjects than in others. We examined the relationships between the teachers' subject-related context and their personal benefits from collaboration across subjects. We also examined the relationship between the attitudes towards the national education policy and personal benefits of teacher collaboration on feedback. Furthermore, we explored the teachers' self-efficacy, which is related to the perceived benefits of collaboration across subjects. Regression analyses were performed. A key finding is that the teachers' subject contexts - their subject-specific beliefs - are related to the personal benefits of teacher collaboration. This means that subject matter contexts might interact with the policy. Further, we found that the more positive teachers in the subjects Norwegian or foreign languages were of the policy, the greater were the benefits in collaboration across subjects. For other teacher groups, it was different. Social studies teachers had the highest personal benefits from collaboration across subjects and the highest policy attitudes, while teachers in Norwegian or foreign languages had the highest self-efficacy. The group of other teachers (science and maths teachers) had low self-efficacy, low policy attitudes, and low personal benefits of collaboration. The implications for school practice, policy design, and further research are discussed.
\end{abstract}

Keywords: policy; writing in content areas; school subjects; self-efficacy; basic skills. 


\section{Introduction}

Teachers' work situations have traditionally been described as relatively isolated: the individual teacher has his or her own classroom in which the frequency of direct colleague interaction or interpreter schemes is limited (Firestone \& Herriot, 1982; Lortie, 1975; Rothland, Cramer, \& Terhart, 2018). However, several school policies (both in Norway and in other countries) have aimed to increase the degree of teacher collaboration outside classroom walls, e.g., through joint planning of teaching, joint preparation of tests, joint correction of tests and course activities aimed at teachers. The course activities can be about academic stimulation in connection with the policy of implementing promotion of for instance writing skills. To some extent, effects from this type of teacher collaboration have been partly demonstrated through improved student performance (Kraft \& Papay, 2014; Jackson \& Bruegmann, 2009; Sun, Loeb, \& Grissom, 2017; Sun, Penuel, Frank, Gallagher, \& Youngs, 2013) but not entirely. An example of the latter is where there is virtually no evidence that course activities actually stimulate teachers' professional development (Jackson, Rockoff, \& Staiger, 2014). A common objection to this type of externally driven course activity is that it is not highly relevant to teachers' individual classroom practices (Sun et al., 2017). The existing empirical support that teacher collaboration does actually benefit teachers' professional development indicates that successful teacher cooperation occurs locally at the individual school and within the same school subject (Sun et al., 2017). Conversely, little is known about the effects of teacher collaboration across school subjects. This article is about how teachers at five schools perceive teacher collaboration across school subjects.

The background for the article is a new cross-curricular national policy (named Ungdomstrinn $i$ utvikling) in Norwegian lower secondary schools focusing on the promotion of students basic skills (Markussen, Carlsten, Seland, \& Sjaastad, 2016). The policy has three key instruments supported by educational authorities: school-based competence development, learning networks among teachers, and advantages of educational resources. One of the goals of the policy is that all students should be trained in basic skills, such as reading literacy, writing in content areas, and numeracy in all subjects. We limited our research endeavour to focus on schools which are promoting writing skills in content areas. We named this writing. What education authorities call team building across school subjects is a key instrument for schools to become more sophisticated learning organisations (Ministry of Education, 2016). While schools are already considered complex organisations for change processes (March \& Olsen, 1976; Weick, 1976), there is no strong historical tradition of close colleague collaboration across school subjects.

The objective of a subject-neutral policy is that secondary school teachers should promote students' basic skills in every subject. This objective could be criticized not to take into account the importance of teachers' subject subcultures characterized by differing beliefs, norms, and practices that affect teachers' work and responses to such promotion of writing across school subjects. We named this beliefs. A vital question is how do subject matter contexts and the differences among them act as filters for this subject-neutral education policy? (Grossman, Stodolsky, \& Knapp, 2004). The teachers' work is embedded in different contexts 
(the school, the academic department, the school subject, the grade level, etc.), each of which can affect how policies are carried out in the classroom. The purpose of this article is to explore empirical relationships between teachers' perceived subject-specific beliefs (Grossman \& Stodolsky, 1994, 1995; Grossman, Stodolsky, \& Knapp, 2004; Siskin, 1994; Stodolsky \& Grossman, 1995) on the one hand and their perceptions of collaboration across subjects (Goddard, Goddard, \& Tschannen-Moran, 2007; Vangrieken, Dochy, Raes, \& Kyndt, 2015), selfefficacy to stimulate writing skills (Bandura, 1977), policy attitudes (Evan, 1996; Gitlin \& Margonis, 1995; Hall \& McGinity, 2015; Schmidt \& Datnow, 2005) and perceived utility of collaboration (Little, 1993; Volante \& Fazio, 2007) on the other hand.

The term subject-specific beliefs has a clear content in research (Grossman et al., 2004). Norwegian secondary level teachers are educated in academic disciplines (e.g., maths, Norwegian language and literature, political science), practical pedagogical education, and subjects' didactics. They also have varying numbers of years of experience in teaching school subjects. The teachers develop educational representations of the school subjects (e.g., notes, power points), and these representations are adjusted and further developed through teaching experiences (Davis \& Krajcik, 2005). We assumed that these experiences are significant for teachers' school-related beliefs (Grossman \& Stodolsky, 1994; Stodolsky \& Grossman, 1995), professional identity (Beijaard, Verloop, \& Vermunt, 2000), perceptions and preferences; in turn, these aspects of beliefs could lead to guidelines for how teachers relate to inputs relevant to how they teach (Lopes, 2009). These subject-specific beliefs can again be linked to participation in specialised school departments in secondary schools (Grossman \& Stodolsky, 1995) and other forms of academic community in a school and between schools (e.g., a more informal community). Experience can, over time, mean a form of specific socialisation in school-related communities where school subject affiliations are understood as subcultures (Siskin, 1994). In this way, subject-specific beliefs can be sustained.

The policy aims to strengthen team building across disciplines (Ministry of Education, 2016). On the Norwegian Directorate for Education and Training website, the challenge with team building is described as follows:

When teachers from different disciplines have a joint responsibility to develop their students' writing skills, it is necessary to collaborate on writing education .... A closer collaboration between the subjects is primarily about teachers from different subjects going into dialogue with each other about what characterises the texts and writing education in the subjects. This will create an increased awareness among subject teachers about which writing education the students actually gets and will be useful knowledge to plan and carry out writing training in their own subject (The Directorate for Education and Training, 2015).

The policy was especially effective for the period 2013-2017 (but local initiatives still promote this teacher collaboration): all Norwegian teachers at the lower secondary level received special offers (courses on the promotion of basic skills) as well as support from representatives of higher education. In addition, 
there has been a considerable amount of competence building through continuing education. The schools that participated in the policy could themselves choose whether to have writing, reading, or numeracy as a policy area. We focused on schools that had chosen writing as a policy area. The reason for this choice was writing is part of the established tradition in some school subjects (e.g., the Norwegian subject and the English subject) while giving feedback on written drafts is, to a lesser extent, part of the tradition in other school subjects, such as mathematics and science. Social studies is a school subject which is considered in this study to be an intermediate category: social science teachers will often relate to argumentative student texts.

The teachers' perceived subject-specific beliefs are important to how teachers relate to policies (Cohen, Raudenbush, \& Ball, 2003; Grossman et al., 2004). A critical factor in policy enactment is how teachers interpret and thus relate to policies (Ball, Maguire, \& Braun, 2012). The theoretical premise in this study is the perceived subject-specific beliefs function as a filter in the enactment process of education policy in the contexts where teachers work (Grossman \& Stodolsky, 1995; Stodolsky \& Grossman, 1995). Therefore, it is interesting to study the relationships between teachers' perceived subject-specific belonging and their experiences of collaboration across subjects, with a focus on the promotion of writing skills. Collaboration across subjects is a key element of the national policy. Furthermore, it is interesting to study how teachers' self-efficacy in stimulating writing skills is related to the perceived benefits of collaboration across subjects (on the basis of teachers' subject-specific beliefs). In addition, we also examined how the teachers' perceptions of the personal benefits of collaboration (Goddard et al., 2007) are related to the usefulness of collaboration across subjects (Vangrieken et al., 2015) based on teachers' subject-specific beliefs.

In this article, the theoretical framework of the study is explained first. Then the empirical survey structure is discussed, followed by the methodology and results. Finally, the results are discussed. Implications for further research and policy design and practice are discussed as well.

\section{Theoretical Framework}

Teachers' teaching is clearly related to students' learning (Chetty, Friedman, \& Rockoff, 2014; McCaffrey, Sass, Lockwood, \& Mihaly, 2009; Rivkin, Hanushek, \& Kane, 2005; Rockoff, 2004). Further, professionals can learn by interacting with other professionals (Herbst \& Mas, 2015). The latter is called a spillover effect. Positive spillover effects from skilled colleagues, for example, can work through two possible mechanisms: a) knowledge transfer from one colleague to another; and b) external pressure in the workplace (Cornelissen, Dustmann, \& Schönberg, 2017; Frank, Lo, \& Sun, 2014).

Transfer of knowledge means that an employee receives a piece of jobrelevant information from another employee and converts it to his/her own knowledge (Papay, Taylor, Tyler, \& Laski, 2016). The best documented effects of transfer can be found in professions that do not require specialised education 
(Cornelissen et al., 2017). Similarly, one can say that external pressures to live up to others' expectations are also documented in professions where low-educated employees observe each other's professional practice and know they are being observed by others, such as a superior (The studies referred to concern workers who put letters in envelopes and the like [Cornelissen et al., 2017.]) We know little about how similar direct observation occurs among teachers. The teaching profession is far more complex than manual professions, and the teachers' instructional skills can hardly be captured through simple indicators (Berliner, 2014).

Direct interactions between teachers take place through, among other things, joint teaching planning, development of local teaching aids, or correction of tests (Ronfeldt, Farmer, McQueen, \& Grissom, 2015) or other collaborative activities that school staff take part in (Sun et al., 2013). Jackson and Bruegmann (2009) and Yuan (2015) found students achieve higher test scores when their teachers have skilled colleagues. Furthermore, Sun et al. (2017) found there are strong positive spillover effects when new teachers at a school are connected to skilled teachers at the same school. In other words, there is evidence to claim teachers learn from other teachers within the same school-subject context.

The tradition in schools has been that it is mainly the mother tongue teacher's task is to respond to the students' written assignments while the task of the foreign-language teacher has been to respond to students' foreign-language writing. In the policy we studied in this work, all teachers are perceived as 'writing teachers'. Bandura's theory of self-efficacy (1977) is about one's belief in one's ability to succeed in specific situations or accomplish a task. The term denotes such expectations are important for the kind of activities one undertakes and how much energy one puts into an action (Tschannen-Moran \& Hoy, 2001). Writing as a basic skill in a subject refers to how confident a teacher can feel about being able to teach writing in a way that students become better writers. Teachers of the subject named Norwegian and teachers of foreign languages can be expected to have more experience in giving explicit responses to students' writing - and hence higher self-efficacy - than other groups of teachers, such as maths and science teachers. Science and maths teachers are expected to have the lowest self-efficacy to stimulate writing skills, while social science teachers constitute a middle category. In other words, we draw on research that assumes that teachers' self-efficacy is specific to the academic context (Tschannen-Moran, Hoy, \& Hoy, 1998).

Teachers' perceptions of the policy (i.e., their policy attitudes) (Schmidt \& Datnow, 2005) are believed to have an impact on the extent to which teachers experience the personal benefits of discussing how they can best stimulate students' writing skills (Goddard et al., 2007; Vangrieken et al., 2015). It is well known from other contexts that teachers can show resistance to changes that are important to their work; this applies, for example, in situations where the premises of the change efforts are not approved (Payne, 2008; Terhart, 2013). Some employees in schools have even sabotaged certain changes: for example, tasks in connection with national tests in Norway were posted online before the tests were to be held (Bergesen, 2006). The theoretically justified expectation is 
the more positive (Schmidt \& Datnow, 2005) teachers are to the policy (measured by policy attitudes), the greater the personal benefits (Goddard et al., 2007) they will experience when delving into interdisciplinary work about stimulating students' writing. It is believed that language teachers have the most positive policy attitudes because the policy relates most to the core of their school subject: stimulating writing. We assume that science and maths teachers, by contrast, have the least positive policy attitudes because the stimulation of writing has not been part of the school subject tradition. For example, a maths teacher could see maths as a separate language to express. Thus, maths teachers can look at the stimulation of written drafts as something that lies naturally outside the scope of the school subject maths. Moreover, one can perceive the division into school subjects as an expression of a natural division of labour between teachers: maths teachers take care of stimulating students' numeracy, language teachers take care of stimulating reading and writing, and so on.

\section{Design, Sample, and Methodology}

To investigate our justified assumptions, we conducted a cross-sectional survey of 110 teachers at five lower secondary schools. The entire teaching staff at each school participated, but completed questionnaires from school leaders, assistants, and teachers as short-term substitutes were not included in the study. In practice, this would mean that almost all of those who were engaged permanently as teachers participated. As aforementioned, we selected schools that had chosen the stimulation of writing as an objective. The data collection took place through an outreach, paper-based questionnaire survey in which all the teachers at the school answered the questionnaire in connection with a compulsory joint meeting. None of the teachers present opted not to participate. At four of the five schools, we received post-filled questionnaires from teachers who were absent at the time of collection (i.e., very few teachers who were not on sick leave or the like at the time of the data collection actively opted out of with' participating in the survey). In other words, we can neglect the selection bias as a potential validity threat. Apart from the question of academic identity, the teachers were asked to mark on a seven-point scale (from ' $1=$ Completely disagree' to ' $7=$ Totally agree') which alternative best matched their own conviction. The paperbased questionnaires that ensured full anonymity were collected by one of the authors and then recorded in a data file and analysed. 


\section{Instruments}

First, we chose to use previously developed instruments as a starting point for adaptation, and we also developed our own instruments based on academic principles created by Haladyna and Rodriguez (2013). Here, we will present the concepts and indicators we used in our study.

The dependent variable in the regression analysis was as follows:

Personal benefits of collaboration across school subjects.

- w31: Discussing with colleagues how to stimulate students' writing has made me a better teacher.

- w32: The learners experience better writing lessons because we teachers discuss writing between us.

- w33: Discussing writing with colleagues contributes to insight into how I can improve my teaching of writing.

- w34: I learn a lot from discussing learners' writing with colleagues.

Independent variables were as follows:

Teachers' subject-specific beliefs.

'I perceive myself first and foremost as ...'

- Language teacher (foreign languages and Norwegian)

- Social studies teacher

- Other teachers (science, maths)

Policy attitudes.

- w1: Because my school promotes writing, I have gained increased insight into how I can improve my teaching.

- w2: I learn a great deal from the fact that my school promotes writing.

- w3: Through participation in the policy endeavour, I have gained increased insight into what I should develop in my teaching.

- w4: Through participation in the policy endeavour, I have learned more about what my strengths in the educational context are.

Self-efficacy to stimulate good writing as basic skills (later referred to as uv4).

- w14: I'm sure I can stimulate writing in such a way that even the weakest students become better writers.

- w15: I'm sure I can give all students feedback that can make them better writers.

\section{Analysis}

We present descriptive statistics and regression analysis where the personal benefits of participating in interdisciplinary groups to promote students' writing skills was the dependent variable. Regression analysis was used to analyse the 
relationships between the variables. The regression models were estimated with the analysis tool IBM SPSS 24. The estimated regression coefficients reflect the strength of the empirical relationships between the variables. The strength increases with increasing numerical value. We performed four regression analyses to have a good basis for drawing conclusions about empirical relationships. We started with a simple regression model and added new independent variables for each model (i.e., variables that gradually increased in complexity). There is a linear relationship between the independent and dependent variables. The dependent variable and the residuals for the dependent variable were approximately normally distributed. No collinearity was detected.

We first wanted to see how the coefficient of the independent variable 'policy attitudes' varied with the perceived subject-specific beliefs with the language subjects, social sciences, and other subjects. We created two dichotomous variables (language subjects and social sciences) that were both coded 0 and 1 . The language-related context means that language $=1$ and social sciences $=0$ while the social science context means that language $=0$ and social sciences $=1$. The context 'other subjects', language $=0$ and social science $=0$, was called the reference context. The variable 'policy attitude' has a coefficient for each context. Both the strength and direction of the policy coefficients can vary between the contexts.

The coefficients in Table 1 must be interpreted with the following background information:

- Benefits, policy attitudes, and coping expectations are transformed into standard scores (z-scores).

- Standard scores have an average of 0 and a standard deviation of 1 . Thus, 0 is a substantially valid value for benefits, policy attitude, and self-efficacy.

- On the original scales from 1 to 7,0 is not a substantially valid value.

- The dummy variables for the school subject context are not standardised variables.

\section{Results}

Table 1 shows the results of the regression analysis while Tables 2, 3, and 4 show descriptive statistics. 
Table 1. Pearson's $r$ between personal benefits and school-based context, policy attitudes, and self-efficacy, respectively, and selected results from four personal benefits regression models as a dependent variable. Highlighted coefficients are significant at 5\%, N $=96$.

\begin{tabular}{|c|c|c|c|c|c|c|c|c|c|}
\hline & \multirow{2}{*}{$\begin{array}{c}\text { Mod } 0 \\
\mathrm{R}\end{array}$} & \multicolumn{2}{|c|}{ Model 1} & \multicolumn{2}{|c|}{ Model 2} & \multicolumn{2}{|c|}{ Model 3} & \multicolumn{2}{|c|}{ Model 4} \\
\hline & & $\mathrm{b}$ & $\mathrm{SE}(\mathrm{b})$ & $\mathrm{b}$ & $\mathrm{SE}(\mathrm{b})$ & $\mathrm{b}$ & $\mathrm{SE}(\mathrm{b})$ & $\mathrm{b}$ & $\mathrm{SE}(\mathrm{b})$ \\
\hline Constant & & $-0,21$ & 0,15 & $-0,19$ & ,15 & $-0,27$ & 0,15 & $-0,11$ & 0,14 \\
\hline Language, 0 / 1 & 0,00 & 0,24 & 0,22 & 0,21 & ,22 & 0,28 & 0,21 & $-0,07$ & 0,21 \\
\hline Social studies, 0 / 1 & 0,23 & 0,76 & 0,30 & 0,70 & 31 & 0,73 & 0,31 & 0,64 & 0,29 \\
\hline Attitudes, z-scores & 0,15 & & & 0,10 & ,10 & $-0,33$ & 0,16 & $-0,37$ & 0,15 \\
\hline Language $x$ attitudes & & & & & & 0,72 & 0,21 & 0,76 & 0,19 \\
\hline Social studies $\mathrm{x}$ attitudes & & & & & & 0,58 & 0,33 & 0,41 & 0,31 \\
\hline Self-efficacy, z-scores & 0,36 & & & & & & & 0,39 & 0,10 \\
\hline Attitudes: & & & & & & & & & \\
\hline Other subjects & & & & & & $-0,33$ & 0,16 & $-0,37$ & 0,15 \\
\hline Language teacher & & & & & & 0,39 & 0,14 & 0,39 & 0,13 \\
\hline Social studies teacher & & & & & & 0,25 & 0,29 & 0,04 & 0,28 \\
\hline $\mathrm{R}^{2}$-adj / $\mathrm{R}^{2} / \Delta \mathrm{R}^{2}$ & & , 045/, & $5 /, 000$ & ,045/, & $5 /, 010$ & ,140/， & 6/, 111 & $263 /, 3$ & $9 /, 124$ \\
\hline
\end{tabular}

Table 2. Descriptive statistics for the dependent variable (personal benefits) and associated indicators broken down by the school context ('I perceive myself first and foremost as ...') and total

\begin{tabular}{|c|c|c|c|c|c|c|}
\hline Subject context & Min & $\operatorname{Max}$ & Mean & SD & Skewness & Kurtosis \\
\hline \multicolumn{7}{|c|}{ Language teachers, $\mathrm{n}=40$} \\
\hline w31 & 1,00 & 7,00 & 5,05 & 1,65 & $-0,59$ & $-0,50$ \\
\hline w32 & 1,00 & 7,00 & 4,73 & 1,65 & $-0,37$ & $-0,69$ \\
\hline w33 & 1,00 & 7,00 & 5,30 & 1,44 & $-1,00$ & 1,00 \\
\hline w34 & 1,00 & 7,00 & 5,35 & 1,56 & $-0,92$ & 0,29 \\
\hline \multicolumn{7}{|c|}{ Social studies teachers, $\mathrm{n}=14$} \\
\hline w31 & 4,00 & 7,00 & 5,71 & 1,07 & $-0,22$ & $-1,10$ \\
\hline w32 & 4,00 & 7,00 & 5,64 & 1,08 & 0,00 & $-1,25$ \\
\hline w33 & 4,00 & 7,00 & 5,93 & 1,14 & $-0,57$ & $-1,11$ \\
\hline w34 & 4,00 & 7,00 & 6,07 & 1,14 & $-0,88$ & $-0,62$ \\
\hline \multicolumn{7}{|l|}{ Other teachers, $n=42$} \\
\hline w31 & 1,00 & 7,00 & 4,86 & 1,41 & $-0,73$ & 0,77 \\
\hline w32 & 1,00 & 7,00 & 4,64 & 1,41 & $-0,36$ & 0,04 \\
\hline w33 & 1,00 & 7,00 & 4,86 & 1,47 & $-0,51$ & 0,03 \\
\hline w34 & 1,00 & 7,00 & 4,76 & 1,66 & $-0,30$ & $-0,62$ \\
\hline \multicolumn{7}{|l|}{ Total $=96 ;$ Alpha $=.94$} \\
\hline w31 & 1,00 & 7,00 & 5,06 & 1,49 & $-0,66$ & 0,09 \\
\hline w32 & 1,00 & 7,00 & 4,82 & 1,50 & $-0,42$ & $-0,31$ \\
\hline w33 & 1,00 & 7,00 & 5,20 & 1,45 & $-0,74$ & 0,29 \\
\hline w34 & 1,00 & 7,00 & 5,20 & 1,61 & $-0,66$ & $-0,32$ \\
\hline
\end{tabular}


Table 3. Descriptive statistics for the independent variable (policy attitudes) and associated indicators broken down by the school subject context and total

\begin{tabular}{|c|c|c|c|c|c|c|}
\hline Subject context & Min & Max & Mean & SD & Skewness & Kurtosis \\
\hline \multicolumn{7}{|c|}{ Language teachers, $n=40$} \\
\hline w1 & 1,00 & 7,00 & 3,75 & 1,37 & 0,23 & 0,38 \\
\hline w2 & 1,00 & 7,00 & 3,60 & 1,35 & 0,27 & 0,37 \\
\hline w3 & 1,00 & 7,00 & 3,78 & 1,35 & 0,10 & 0,00 \\
\hline w4 & 1,00 & 6,00 & 3,50 & 1,20 & $-0,14$ & $-0,50$ \\
\hline \multicolumn{7}{|c|}{ Social studies teachers, $\mathrm{n}=14$} \\
\hline w1 & 1,00 & 5,00 & 4,07 & 1,27 & $-1,47$ & 1,54 \\
\hline w2 & 1,00 & 6,00 & 4,00 & 1,18 & $-0,99$ & 2,67 \\
\hline w3 & 2,00 & 6,00 & 4,21 & 0,97 & $-0,49$ & 1,30 \\
\hline w4 & 1,00 & 5,00 & 3,86 & 1,17 & 1,38 & 1,82 \\
\hline \multicolumn{7}{|l|}{ Other teachers, $n=42$} \\
\hline w1 & 1,00 & 7,00 & 3,69 & 1,20 & 0,19 & 0,49 \\
\hline w2 & 1,00 & 7,00 & 3,43 & 1,29 & 0,27 & 0,51 \\
\hline w3 & 1,00 & 6,00 & 3,57 & 1,13 & $-0,56$ & 0,01 \\
\hline w4 & 1,00 & 5,00 & 2,86 & 1,18 & $-0,08$ & $-0,79$ \\
\hline \multicolumn{7}{|c|}{ Total = 96; Alpha $=.91$} \\
\hline w1 & 1,00 & 7,00 & 3,77 & 1,28 & 0,01 & 0,21 \\
\hline w2 & 1,00 & 7,00 & 3,58 & 1,30 & 0,12 & 0,26 \\
\hline w3 & 1,00 & 7,00 & 3,75 & 1,21 & $-0,19$ & 0,13 \\
\hline w4 & 1,00 & 6,00 & 3,27 & 1,24 & $-0,23$ & $-0,68$ \\
\hline
\end{tabular}

Table 4. Descriptive statistics for the independent variable (self-efficacy) and associated indicators broken down by the school subject context and total

\begin{tabular}{|c|c|c|c|c|c|c|}
\hline Subject context & Min & Max & Mean & SD & Skewness & Kurtosis \\
\hline \multicolumn{7}{|c|}{ Language teachers, $n=40$} \\
\hline w14 & 3,00 & 7,00 & 5,32 & 1,16 & $-0,37$ & $-0,64$ \\
\hline w15 & 3,00 & 7,00 & 5,50 & 1,11 & $-0,53$ & $-0,37$ \\
\hline \multicolumn{7}{|c|}{ Social studies teachesr, $\mathrm{n}=14$} \\
\hline w14 & 2,00 & 6,00 & 4,57 & 1,34 & $-0,85$ & 0,10 \\
\hline w15 & 2,00 & 6,00 & 5,14 & 1,17 & $-1,67$ & 3,06 \\
\hline \multicolumn{7}{|l|}{ Other teachers, $n=42$} \\
\hline w14 & 2,00 & 7,00 & 4,14 & 1,34 & 0,05 & $-0,87$ \\
\hline w15 & 2,00 & 7,00 & 4,48 & 1,27 & $-0,39$ & $-0,45$ \\
\hline \multicolumn{7}{|c|}{ Total $=96 ;$ Alpha $=, 86$} \\
\hline w14 & 2,00 & 7,00 & 4,70 & 1,37 & $-0,29$ & $-0,71$ \\
\hline w15 & 2,00 & 7,00 & 5,00 & 1,27 & $-0,59$ & $-0,14$ \\
\hline
\end{tabular}

In the following, we comment on results from the regression analyses. The analysis shows no indications of collinearity, and all the tolerance values are over 20. Model 4 has the highest value of $R^{2}$-adj $=, 263, R^{2}=, 309$ and $\Delta R^{2}=, 124$. This indicates that Model 4 fits data better than Models 1 to 3. We, therefore, concentrate on commenting on the results for this model.

The effect of policy attitudes on personal benefits of collaboration across subjects is calculated on the basis of the results for Model 4 in Table 1: 
$\left(b_{\text {attitude }}+b_{\text {language }} \cdot\right.$ language $+b_{\text {socialstudies }} \cdot$ social studies $)=(-, 37+, 76$ $\cdot$ language,$+ 41 \cdot$ socialstudies)

«Other subjects», language $=0$ and social studies $=0$

$\left(b_{\text {attitude }}+b_{\text {language }} \cdot\right.$ language $+b_{\text {socialstudies }} \cdot$ social studies $)=(-, 37+, 76 \cdot 0+$ $, 41 \cdot 0)=-, 37$

Language teachers, language $=1$ and social studies $=0$

$\left(b_{\text {attitude }}+b_{\text {language }}\right.$ language $+b_{\text {socialstudies }} \cdot$ social studies $)=(-, 37+, 76 \cdot 1+$ $, 41 \cdot 0)=-, 37+, 76=, 39$

Social studies teachers, language $=0$ and social studies $=1$

$\left(b_{\text {attitude }}+b_{\text {language }} \cdot\right.$ language $+b_{\text {socialstudies }} \cdot$ social studies $)=(-, 37+, 76 \cdot 0+$ $, 41 \cdot 1)=-, 37+, 41=, 04$

These results show the following: in the group 'other subjects' (made up of science and math teachers), we found the more negative this group sees the policy, the higher they experience their personal benefits from participating in collaboration across subjects. In the group 'language teachers' (made up of teachers of the subjects named Norwegian and foreign languages) we found the more positively this group looks at the policy, the higher they experience their personal benefits from participating in collaboration across subjects. In the group 'social science teachers', we found a negligible context.

The descriptive statistics show that measurements of concepts have good reliability. The values of skewness and kurtosis are acceptable. This implies the average values can be interpreted as usable indications of the central tendency. The spread (measured by standard deviation) is partly high, partly moderate.

\section{Discussion}

The intentions of the policy are formulated as policies applicable to all school subjects: the authorities provide support for local development work in reading and writing in all subjects at secondary school level (as well as class management). This involves ambitions for interdisciplinary teacher collaboration. The schools choose the area of policy themselves, and they are allocated resources from the universities in accordance with the choice. It can be assumed that policy on numeracy, reading, and writing in all school subjects can be considered important for school development. The critical question is how the intentions of this education policy affect the actual teaching practice (Ball et al., 2012). There is no empirical evidence on the latter in this study. Future research can explore how policy is actually enacted through teaching and how students learn basic skills on the basis of teaching.

The material has been collected at schools that have chosen to promote students' writing. The findings are valid for the schools included in the survey. Future research must clarify the question of the external validity of the results. The result of the interdisciplinary policy on writing is not something that is measured in Norway through a national test or examination, for example. That is why there is no measurable indicator of achievement of results and hence no control options to be able to hold schools accountable for results. When there is 
not one (or more) indicator(s) on goal achievement, the teachers' perceptions and preferences will be all the more important for their actions. It is well known from previous research that external factors that are not perceived as convincing can easily be downgraded in importance (Terhart, 2013). The issue of nonmeasurable policy ambitions has become even more important in Norway in light of the fact that this is a strengthened ambition: schools are expected to realise non-measurable ambitions of so-called cross-disciplinary topics. However, there is no interdisciplinary examination of these ambitions through exams or national tests. Thus, the enactment of the cross-curricular intentions will depend on the teachers' decisions. One implication of this study is more research is needed on how teachers actually enact teaching in accordance with the intentions that writing should be stimulated in all subjects (Ball et al., 2012).

The theoretical premise of the study is that the school subject's context is regarded as a mould for the policy's enactment (Grossman et al., 2004). Schoolspecific characteristics are claimed to give rise to distinct subcultures in a school's organisation (Siskin, 1994); this factor will also mediate policy. A key finding in our study is that the subject-specific beliefs are clearly related to the perceived personal benefits of collaboration. This is what we expected. Thus, we find empirical support to argue beliefs greatly impact how teachers think about their work to stimulate students' writing skills. An avenue for future research will be to investigate how subject-specific beliefs affect the enactment of the policy in actual teaching.

As expected, we found the more positive teachers of the subjects (Norwegian and foreign languages) were to the policy in question, the greater the benefits they obtained from collaboration across subjects. For social science teachers, there is no such significant relation, while for the group 'other teachers' (science and maths teachers), we found the weaker the policy attitudes, the greater the personal benefits from collaboration across subjects on writing. The latter can be interpreted as follows: teachers who dislike the policy can still appreciate the collaboration across subjects because these give the teachers personal benefits in their work as teachers. Social science teachers have the highest average personal benefits from collaboration across subjects and the highest policy attitudes. This is not entirely in line with our expectations, but the result is nevertheless plausible because social science teachers read many student texts where they have opportunities to provide feedback on the writing of the tasks. Thus, we believe this group sees the potential for learning from colleagues. Language teachers have experience in providing feedback on student texts and have adequate prior knowledge. And, as expected, language teachers have the highest self-efficacy to stimulate written assignments. Thus, it is not so surprising that language teachers have lower personal benefits of collaboration across subjects compared with science teachers and social studies teachers. Social studies teachers often encounter student texts to give feedback on. This gives teachers of social studies opportunities to stimulate writing skills. We believe that this explains their high personal benefits in collaborative activities. Policy attitudes of social studies teachers are also related to their personal benefits of collaboration. 
The group 'other teachers' (science and maths teachers) have, as expected, the lowest self-efficacy to stimulate students' writing. Providing feedback on students' writing is not present as a topic in the universities' science programs, and stimulating writing is only marginally present in the science subjects' teaching courses at the teacher education institutions (this also applies to the former general teacher education). In light of this, it is no wonder this group of teachers has the lowest self-efficacy. National policies can provoke teacher resistance. It is striking that the group 'other teachers' has the lowest policy attitudes of these groups. Kelchtermans (2006) and Hargreaves (1994) point out forced collegiality can provoke resistance among teachers. We do not know if the type of forced collegiality embedded in the policy of stimulating students' writing skills has actually awakened resistance through enactment via teaching. One possible conclusion, however, is that in change processes without measurable achievement of results, it is important to win the target group's hearts and minds through convincing arguments. The group 'other teachers' is the group that experiences the lowest personal benefits from collaboration across groups of teachers and thus can be the group that should be particularly convinced of the excellence of the policy. As this group has the lowest selfefficacy to stimulate writing skills, the potential for learning from colleagues is present. However, we know nothing about whether this actually matters to their teaching.

We found subject-bound differences in teachers' perceptions of collaboration across subjects: the main conclusion is that teachers' subjectspecific beliefs are clearly related to their perceived personal benefits of collaboration with other teachers across school subjects. Therefore, we believe that education policy on collaboration across school subjects is mediated through subject matter contexts. However, we do not know how subject-specific beliefs affect the enactment of the policy in actual teaching.

\section{References}

Ball, S. J., Maguire, M., \& Braun, A. (2012). How schools do policy: Policy enactments in secondary schools. London: Routledge.

Bandura, A. (1977). Self-efficacy: Toward a unifying theory of behavioral change. Psychological Review, 84(2), 191.

Beijaard, D., Verloop, N., \& Vermunt, J. D. (2000). Teachers' perceptions of professional identity: An exploratory study from a personal knowledge perspective. Teaching and Teacher Education, 16(7), 749-764.

Bergesen, H. O. (2006). Kampen om kunnskapsskolen [The tug-of-war on the knowledge school]. Oslo: Universitetsforlaget.

Berliner, D. C. (2014). Exogenous variables and value-added assessments: A fatal flaw. Teachers College Record, 116(1), 1-31.

Chetty, R., Friedman, J. N., \& Rockoff, J. E. (2014). Measuring the impacts of teachers: Evaluating bias in teacher value-added estimates. American Economic Review, 104(10), 2593-2632.

Cohen, D. K., Raudenbush, S. W., \& Ball, D. L. (2003). Resources, instruction, and research. Educational Evaluation and Policy Analysis, 25(2), 119-142. 
Cornelissen, T., Dustmann, C., \& Schönberg, U. (2017). Peer effects in the workplace. American Economic Review, 107(2), 425-56.

Davis, E. A., \& Krajcik, J. S. (2005). Designing educative curriculum materials to promote teacher learning. Educational Researcher, 34(3), 3-14.

Firestone, W. A., \& Herriott, R. E. (1982). Two images of schools as organizations: An explication and illustrative empirical test. Educational Administration Quarterly, 18(2), 39-59.

Gitlin, A., \& Margonis, F. (1995). The political aspect of policy: Teacher resistance as good sense. American Journal of Education, 103(4), 377-405.

Goddard, Y. L., Goddard, R. D., \& Tschannen-Moran, M. (2007). A theoretical and empirical investigation of teacher collaboration for school improvement and student achievement in public elementary schools. Teachers College Record, 109(4), 877-896.

Grissom, J. A., Loeb, S., \& Nakashima, N. (2014). Strategic involuntary teacher transfers and teacher performance: Examining equity and efficiency. Journal of Policy Analysis and Management, 33(1), 112-140.

Grossman, P. L., \& Stodolsky, S. S. (1995). Content as context: The role of school subjects in secondary school teaching. Educational Researcher, 24(8), 5-23.

Grossman, P. L., \& Stodolsky, S. S. (1994). Considerations of content and the circumstances of secondary school teaching. Review of research in education, 20(1), 179-221.

Grossman, P., Stodolsky, S. S., \& Knapp, M. S. (2004). Making subject matter part of the equation: The intersection of policy and content. An occasional paper. Washington DC: University of Washington.

Haladyna, T. M., \& Rodriguez, M. C. (2013). Developing and validating test items. London: Routledge.

Hall, D. \& McGinity, R. (2015). Conceptualizing teacher professional identity in neoliberal times: Resistance, compliance and policy. Education Policy Analysis Archives, 23(88), 1-17.

Hargreaves, A. (1994). Changing teachers, changing times: Teachers' work and culture in the postmodern age. New York, NY: Teachers College Press.

Herbst, D., \& Mas, A. (2015). Peer effects on worker output in the laboratory generalize to the field. Science, 350(6260), 545-549.

Jackson, C. K., \& Bruegmann, E. (2009). Teaching students and teaching each other: The importance of peer learning for teachers. American Economic Journal: Applied Economics, 1(4), 85-108.

Jackson, C. K., Rockoff, J. E., \& Staiger, D. O. (2014). Teacher effects and teacher-related policies. Annual Review of Economics, 6, 801-825.

Kelchtermans, G. (2006). Teacher collaboration and collegiality as workplace conditions. A review. Zeitschrift für Pädagogik, 52(2), 220-237.

Kraft, M. A., \& Papay, J. P. (2014). Can professional environments in schools promote teacher development? Explaining heterogeneity in returns to teaching experience. Educational Evaluation and Policy Analysis, 36(4), 476-500.

Little, J. W. (1993). Teachers' professional development in a climate of educational policy. Educational Evaluation and Policy Analysis, 15(2), 129-151. 
Lopes, A. (2009). Teachers as professionals and teachers' identity construction as an ecological construct: An agenda for research and training drawing upon a biographical research process. European Educational Research Journal, 8(3), 461-475.

Lortie, D. (1975). Schoolteacher: A sociological analysis. Chicago, IL: University of Chicago Press.

March, J. G., \& Olsen, J. P. (1976). Organizational learning and the ambiguity of the past. Ambiguity and Choice in Organizations, 2(1), 54-68.

Markussen, E., Carlsten, T. C., Seland, I., \& Sjaastad, J. (2016). Fra politisk visjon til virkeligheten $i$ klasserommet. Evaluering av virkemidlene i Ungdomstrinn i utvikling. Delrapport 2. [From political vision towards realities in the classroom. Evaluation of Development of lower secondary school]. Oslo: NIFU.

McCaffrey, D. F., Sass, T. R., Lockwood, J. R., \& Mihaly, K. (2009). The intertemporal variability of teacher effect estimates. Education Finance and Policy, 4(4), 572-606.

Ministry of Education (2016). Ungdomstrinn i utvikling. Lagbygging for elevenes læring og motivasjon. [Development of lower secondary school: Team building for students' learning and motivation]. Downloaded from:

https://www.regjeringen.no/no/tema/utdanning/grunnopplaring/innsiktsart ikler/ungdomstrinn-i-utvikling/id737594/

Nye, B., Konstantopoulos, S., \& Hedges, L. V. (2004). How large are teacher effects? Educational Evaluation and Policy Analysis, 26(2), 237-257.

Papay, J., Taylor, E. S., Tyler, J. \& Laski, M. (2016). Learning job skills from colleagues at work: Evidence from a field experiment using teacher performance data. Downloaded from http://www.nber.org/papers/w21986

Payne, C. M. (2008). So much policy, so little change: The persistence of failure in urban schools. Cambridge, MA: Harvard Education Press.

Rivkin, S. G., Hanushek, E. A., \& Kain, J. F. (2005). Teachers, schools, and academic achievement. Econometrica, 73(2), 417-458.

Rockoff, J. E. (2004). The impact of individual teachers on student achievement: Evidence from panel data. The American Economic Review, 94(2), 247-252.

Ronfeldt, M., Farmer, S. O., McQueen, K., \& Grissom, J. A. (2015). Teacher collaboration in instructional teams and student achievement. American Educational Research Journal, 52(4), 475-514.

Rothland, M., Cramer, C., \& Terhart, E. (2018). Forschung zum Lehrerberuf und zur Lehrerbildung [Research on the teaching profession and teacher education]. In R. Tippelt \& B. Schmidt-Hertha (Eds.), Handbuch Bildungsforschung [Handbook of educational research] (pp. 1011-1034). Wiesbaden: Springer Verlag.

Schmidt, M., \& Datnow, A. (2005). Teachers' sense-making about comprehensive school policy: The influence of emotions. Teaching and Teacher Education, 21(8), 949-965.

Shachar, H., \& Shmuelevitz, H. (1997). Implementing cooperative learning, teacher collaboration and teachers' sense of efficacy in heterogeneous junior high schools. Contemporary Educational Psychology, 22(1), 53-72.

Siskin, L. S. (1994). Realms of knowledge: Academic departments in secondary schools. London: Routledge.

Skaalvik, E. M., \& Skaalvik, S. (2009). Does school context matter? Relations with teacher burnout and job satisfaction. Teaching and Teacher Education, 25(3), 518-524. 
Stodolsky, S. S., \& Grossman, P. L. (1995). The impact of subject matter on curricular activity: An analysis of five academic subjects. American Educational Research Journal, 32(2), 227-249.

Sun, M., Garrison, A., Larson, C. J., \& Frank, K. A. (2014). Exploring colleagues' professional influences on mathematics teachers' learning. Teachers College Record, 116(2), 305-335.

Sun, M., Penuel, W. R., Frank, K. A., Gallagher, H. A., \& Youngs, P. (2013). Shaping professional development to promote the diffusion of instructional expertise among teachers. Educational Evaluation and Policy Analysis, 35(3), 344-369.

Sun, M., Loeb, S., \& Grissom, J. A. (2017). Building teacher teams: Evidence of positive spillovers from more effective colleagues. Educational Evaluation and Policy Analysis, 39(1), 104-125.

The Directorate for Education and Training (2015) Skrive mye i alle fag og bruke skriving i kunnskapstilegnelsen. [A lot of writing in all school subject and using writing in knowledge acquisition]. Downloaded from: https:// www.udir.no/laring-og-trivsel/lareplanverket/grunnleggendeferdigheter/skriving/prinsipper-for-god-skriveopplaring/prinsipp-1/

Tschannen-Moran, M., \& Hoy, A. W. (2001). Teacher efficacy: Capturing an elusive construct. Teaching and Teacher Education, 17(7), 783-805.

Tschannen-Moran, M., Hoy, A. W., \& Hoy, W. K. (1998). Teacher efficacy: Its meaning and measure. Review of Educational Research, 68(2), 202-248.

Terhart, E. (2013). Teacher resistance against school policy: Reflecting an inconvenient truth. School Leadership \& Management, 33(5), 486-500.

Yuan, K. (2015). A value-added study of teacher spillover effects across four core subjects in middle schools. Education Policy Analysis Archives, 23(38), 1-24.

Vangrieken, K., Dochy, F., Raes, E., \& Kyndt, E. (2015). Teacher collaboration: A systematic review. Educational Research Review, 15, 17-40.

Volante, L., \& Fazio, X. (2007). Exploring teacher candidates' assessment literacy: Implications for teacher education policy and professional development. Canadian Journal of Education, 30(3), 749-770.

Weick, K. E. (1976). Educational organizations as loosely coupled systems. Administrative Science Quarterly, 1(1), 1-19. 